\title{
Perancangan Sistem Monitoring dan Evaluasi Absensi Pegawai Politeknik Negeri Ujung Pandang
}

\author{
Kasim $^{1)}$, Rini Nur ${ }^{2)}$, Muji Iswanti ${ }^{3)}$ \\ 1,2,3 Teknik Elektro, Politeknik Negeri Ujung Pandang \\ Email: ${ }^{1}$ kasim@ @oliupg.ac.id, ${ }^{2}$ rini@ poliupg.ac.id, ${ }^{3}$ muji.iswanti@gmail.com²
}

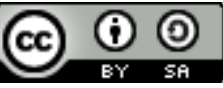

Abstract

Sistem absensi berguna memantau kondisi kehadiran setiap orang yang berada pada lingkungan pekerjaan baik institusi maupun perusahaan. Absensi pada suatu institusi meliputi adanya nama pegawai, departemen, jabatan, tanggal/hari, dan jam kerja. Hal ini diperlukan untuk mengetahui alokasi waktu jam kerja dari setiap karyawan yaitu mulai dari jam masuk, jam keluar, waktu keterlambatan, dan waktu cepat pulang. Pada Politeknik Negeri Ujung Pandang dibutuhkan laporan tentang kehadiran pegawai yang sesuai dengan format yang berlaku dan berisi perhitungan persen pengurangan tunjangan kinerja pegawai dan sanksi pegawai. Untuk memonitoring absensi pegawai, kepala departemen adalah salah satu aktor yang paling andil. Pada penelitian ini, data yang digunakan adalah data log absensi yang dilakukan oleh pegawai setiap harinya pada bulan Juli 2017. Sistem yang dibangun secara otomatis dapat menampilkan waktu keterlambatan, waktu cepat pulang, persen pemotongan tunjangan kinerja, dan sanksi pegawai. Dalam sistem ini tersedia fitur untuk menampilkan persen pengurangan tunjangan dan sanksi yang telah dicantumkan pada Pasal 6 Peraturan Menteri Riset, Teknologi, dan Pendidikan Tinggi Republik Indonesia Nomor 31 Tahun 2016 dan Pasal 7 Peraturan Pemerintah Republik Indonesia Nomor 53 Tahun 2010.

Keywords: absensi, tunjangan kinerja, monitoring

\section{PENDAHULUAN}

Absensi pegawai merupakan salah satu hal penting untuk mengetahui kehadiran seseorang dalam suatu tempat atau institusi. Sistem absensi berguna memantau kondisi kehadiran setiap orang yang berada pada lingkungan pekerjaan baik institusi maupun perusahaan. Absensi pada suatu institusi meliputi adanya nama pegawai, departemen, jabatan, tanggal/hari, dan jam kerja. Hal ini diperlukan untuk mengetahui alokasi waktu jam kerja dari setiap karyawan yaitu mulai dari jam masuk, jam keluar, waktu keterlambatan, dan waktu cepat pulang. Selain itu dengan adanya sistem absensi kepegawaian peraturan kedisiplinan dapat terwujud dengan adanya data real.

Absensi Pegawai yang dilakukan Politeknik Negeri Ujung Pandang saat ini menggunakan alat fingerprint yang dilengkapi dengan aplikasi Time Attendance System. Aplikasi Time Attendance System yang digunakan memiliki fitur yang sangat lengkap dalam mengelola data kehadiran pegawai. Pada aplikasi Time Attendance System terdapat beberapa fitur laporan kehadiran secara umum, namun belum semua kebutuhan pelaporan kehadiran pegawai di Politeknik Negeri Ujung Pandang tersedia pada aplikasi tersebut. Pada Politeknik Negeri Ujung Pandang dibutuhkan laporan tentang kehadiran pegawai yang sesuai dengan format yang berlaku dan berisi perhitungan persen pengurangan tunjangan kinerja pegawai dan sanksi pegawai.

Saat ini, laporan pemotongan tunjangan berdasarkan kehadiran pegawai diolah oleh staf menggunakan tools tambahan. Laporan tersebut belum mencakup tentang sanksi yang dikenakan berdasarkan kehadiran yang sesuai dengan Pasal 7 Peraturan Pemerintah Republik Indonesia Nomor 53 Tahun 2010.

Berdasarkan permasalahan di atas, permasalahan ini dapat diselesaikan dengan membangun sebuah sistem yang secara otomatis dapat menampilkan waktu keterlambatan, waktu cepat pulang, persen pemotongan tunjangan kinerja, dan sanksi pegawai. Dalam sistem tersebuttersedia fitur untuk menampilkan persen pengurangan tunjangan dan sanksi yang telah dicantumkan pada Pasal 6 Peraturan Menteri Riset, Teknologi, dan Pendidikan Tinggi Republik Indonesia Nomor 31 Tahun 2016 dan Pasal 7 Peraturan Pemerintah Republik Indonesia Nomor 53 Tahun 2010. 


\section{KAJIAN LITERATUR, TEORI ATAU PEGEMBANGAN HIPOTESIS (JIKA ADA)}

\subsection{Sistem}

"Sistem adalah suatu jaringan kerja dari prosedur-prosedur yang salingberhubungan, berkumpul bersamasama untuk melakukan kegiatan atau untukmenyelesaikan suatu sasaran yang tertentu." (Jogiyanto dalam Winarti, Dwi, Tanpa Tahun).

\subsection{Monitoring dan Evaluasi}

Monitoring merupakan aktivitas internal proyek yang dirancang untuk mengidentifikasi feedback konstan pada setiap progres dari proyek tersebut, termasuk masalah-masalah yang dihadapi dan efisiensi dari implementasi proyek tersebut (Hewitt dalam Muktiali, Mohammad, 2009).

Sementara itu evaluasi merupakan proses penilaian pencapaian tujuan dan pengungkapan masalah kinerja program/kegiatan untuk memberikan umpan balik bagi peningkatan kualitas kinerja program/kegiatan. Evaluasi pada dasarnya akan bermanfaat dalam merancang proyek-proyek yang lebih baik di masa depan. Hal ini terkait dengan manfaat evaluasi itu sendiri yang mampu mengidentifikasi dampak dari sebuah proyek, sehingga dampak negatifnya dapat direduksi bahkan dihilangkan (Hewitt dalam Muktiali, Mohammad, 2009). Tidak adanya sistem evaluasi yang efektif pada sebuah proyek dapat mengakibatkan dampak negatif dari proyek tersebut akan semakin meningkat karena tidak mampu menghasilkan keuntungan yang diharapkan (Hewitt dalam Muktiali, Mohammad, 2009).

\subsection{Lampiran Peraturan Menteri Nomor 31 Tahun 2016}

Perhitungan Penilaian Tunjangan Kinerja Semester I bobot masing-masing komponen penilaian Tunjangan Kinerja pada tahun 2016 semester I, yaitu:
- Kehadiran memiliki bobot $100 \%$ (seratus persen);

- Kinerja memiliki bobot 0\% (nol persen); dan

- Integritas memiliki bobot 0\% (nol persen).

Adapun penghitungan pengurangan Tunjangan Kinerja dari komponen kehadiran adalah sebagai berikut:

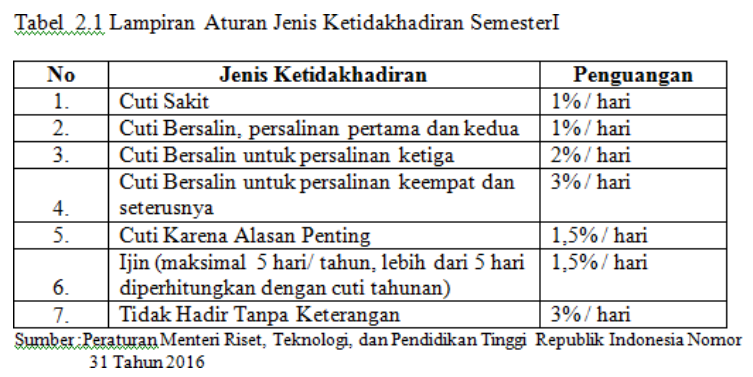

Tabel 2.2 Lampiran Aturan Keterlambatan Semester I

\begin{tabular}{|l|l|l|}
\hline \multicolumn{1}{|c|}{$\begin{array}{c}\text { Keterlambatan } \\
\text { (menit) }\end{array}$} & Waktu Kedatangan & Pengurangan (\%) \\
\hline $0-60$ & $07.30-08.30$ & 0,25 \\
\hline $61-75$ & $08.31-08.45$ & 0,5 \\
\hline $76-90$ & $08.46-09.00$ & 0,75 \\
\hline $91-105$ & $09.01-09.15$ & 1 \\
\hline $106-120$ & $09.16-09.30$ & 1,23 \\
\hline$>121-240$ & $09.31-11.30$ & 1,5 \\
\hline $\begin{array}{l}\text { Sumber-Peraturan Menteri Riset, Teknologi, dan Pendidikan Tinggi Republik Indonesia Nomor } \\
\text { 31 Tahun 2016 }\end{array}$
\end{tabular}

Tabel 2.3 Lampiran Aturan Pergi Sebelum Waktu Semester I

\begin{tabular}{|c|c|}
\hline PSW (Menit) & Pengurangan (\%) \\
\hline $0-60$ & 0,25 \\
\hline $61-75$ & 0,5 \\
\hline $76-90$ & 0,75 \\
\hline $91-105$ & 1 \\
\hline $106-120$ & 1,25 \\
\hline$>121-240$ & 1,5 \\
\hline
\end{tabular}

Perhitungan Penilaian Tunjangan Kinerja Semester II bobot masing-masing komponen penilaian Tunjangan Kinerja pada tahun 2016 semester II dan seterusnya, yaitu:

- Kehadiran memiliki bobot 30\% (tiga puluh persen);

- Kinerja memiliki bobot 40\% (empat puluh persen); dan

- Integritas memiliki bobot 30\% (tiga puluh persen).

Penilaian Tunjangan Kinerja dari aspek komponen kehadiran dilakukan berdasarkan kehadiran Pegawai dikurangi dengan ketidakhadiran, keterlambatan, dan/atau pulang sebelum waktunya. Adapun perhitungan 
pengurangan Tunjangan Kinerja dari komponen kehadiran adalah sebagai berikut:

Tabel 2.4 LampiranAturan Jenis Ketidakhadiran Semester II

\begin{tabular}{|c|l|l|}
\hline No & \multicolumn{1}{|c|}{ Jenis Ketidakhadiran } & \multicolumn{1}{c|}{ Penguangan } \\
\hline 1. & Cuti Sakit & $1 \% /$ hari \\
\hline 2. & Cuti Bersalin, persalinan pertama dan kedua & $1 \% /$ hari \\
\hline 3. & Cuti Bersalin untuk persalinan ketiga & $2 \% /$ hari \\
\hline 4. & $\begin{array}{l}\text { Cuti Bersalin untuk persalinan keempat dan } \\
\text { seterusnya }\end{array}$ & $3 \% /$ hari \\
\hline 5. & Cuti Karena Alasan Penting & $3 \% /$ hari \\
\hline 6. & $\begin{array}{l}\text { Ijin (maksimal 5 hari/ tahun, lebih dari } 5 \text { hari } \\
\text { diperhitungkan dengan cuti tahunan) }\end{array}$ & $3 \% /$ hari \\
\hline 7. & Tidak Hadir Tanpa Keterangan & $5 \% /$ hari \\
\hline Sumber:-PeraturanMenteri Riset, Teknologi, dan Pendidikan Tinggi Republik Indonesia Nomor \\
31 Tahun 2016
\end{tabular}

Tabel 2.5 Lampiran Aturan Keterlambatan Semester II

\begin{tabular}{|c|c|c|}
\hline $\begin{array}{c}\text { Keterlambatan } \\
\text { (menit) }\end{array}$ & Waktu Kedatangan & Pengurangan $(\%)$ \\
\hline $0-60$ & $07.30-08.30$ & 0,25 \\
\hline $61-75$ & $08.31-08.45$ & 0,5 \\
\hline $76-90$ & $08.46-09.00$ & 1 \\
\hline $91-105$ & $09.01-09.15$ & 1,5 \\
\hline $106-120$ & $09.16-09.30$ & 2 \\
\hline$>121-240$ & $09.31-11.30$ & 2,5 \\
\hline
\end{tabular}

Tabel 2.6 Lampiran Aturan Pergi Sebelum Waktu Semester II

\begin{tabular}{|l|l|}
\hline \multicolumn{1}{|c|}{ PSW (Menit) } & \multicolumn{1}{c|}{ Pengurangan (\%) } \\
\hline $0-60$ & 0,25 \\
\hline $61-75$ & 0,5 \\
\hline $76-90$ & 1 \\
\hline $91-105$ & 1,5 \\
\hline $106-120$ & 2 \\
\hline$>121-240$ & 2,5 \\
\hline \\
Sumber-:PeraturanMenteri Riset, Teknologi, dan Pendidikan Tinggi Republik Indonesia Nomor \\
31 Tahun 2016
\end{tabular}

\subsection{Lampiran Peraturan Pemerintah Republik Indonesia Nomor 53 Tahun 2010}

\begin{tabular}{|c|c|c|c|}
\hline No & Tingkat dan Jenis Hukuman & Ketidakhadiran & Keterangan \\
\hline 1. & $\begin{array}{l}\text { Hukuman Ringan } \\
\text { a. Teguran Lisan } \\
\text { b. Teguran Tertulis } \\
\text { c. Pernyataan Tidak Puas Secara } \\
\text { Tertulis }\end{array}$ & $\begin{array}{l}5 \text { Hari } \\
6-10 \text { Hari } \\
11-15 \text { Hari }\end{array}$ & $5-15$ Hari \\
\hline 2. & $\begin{array}{l}\text { Hukuman Sedang } \\
\text { a. Penundaan Kenaikan Gaji } \\
\text { Berkala } 1 \mathrm{Th} . \\
\text { b. Penundaan Kenaikan Pangkat } 1 \\
\text { Th. } \\
\text { c. Penurunan Pangkat } 1 \text { tingkat } \\
\text { selama } 1 \mathrm{Th} . \\
\end{array}$ & $\begin{array}{l}16-20 \text { Hari } \\
21-25 \text { Hari } \\
26-30 \text { Hari }\end{array}$ & $16-30 \mathrm{Han}$ \\
\hline 3. & $\begin{array}{l}\text { Hukuman Berat } \\
\text { a. Penurunan Pangat } 1 \text { tingkat } \\
\text { selama } 3 \text { Th. } \\
\text { b. Pemindahan dalam rangka } \\
\text { Penurunan Jabatan } 1 \text { tingkat. } \\
\text { c. Pembebasan Jabatan } \\
\text { d. Pemberhentian dengan } \\
\text { hormat tidak dengan hormat }\end{array}$ & $\begin{array}{l}31-35 \text { hari } \\
36-40 \text { Hari } \\
41-45 \text { Hari } \\
46 \text { Hari atau } \\
\text { Lebih }\end{array}$ & $\begin{array}{l}31 \text { atau } \\
\text { lebih }\end{array}$ \\
\hline
\end{tabular}

\section{METODE PENELITIAN}

Metode penelitian pada jurnal ini terdiri dari :

\section{a. Prosedur Penelitian}

Prosedur penelitian diperlukan agar penelitian yang dikerjakan dapat terstruktur sehingga hasil yang didapatkan sesuai dengan tujuan pada penelitian.

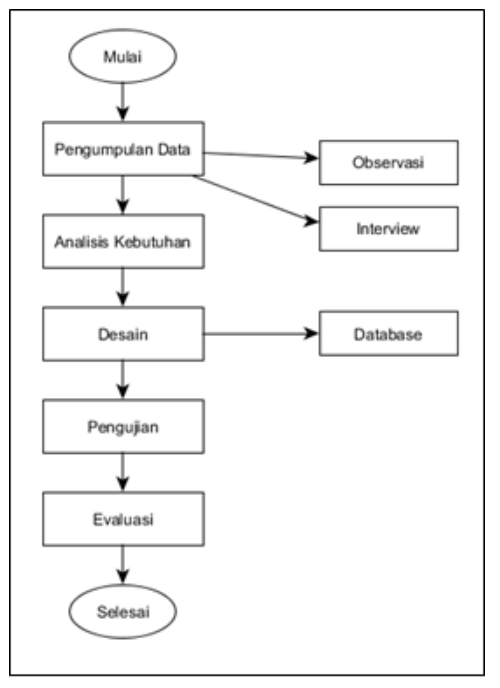

Gambar 3.1 Prosedur penelitian

1) Pengumpulan Data

Pengumpulan data dilakukan melalui studi literature dari jurnal, tugas akhir/tesis/disertai, dan website. Studi tersebut berguna dalam penentuan topik dan dasar teori penelitian. Dari hasil studi tersebut, dapat diketahui perkembangan teknologi, permasalahan, penelitian yang telah dilakukan, desain, dan implementasi berbasis website.

a. Observasi. Observasi memiliki peran yang sangat penting dalam penelitian ini. Sebagian besar penelitian dilakukan di bagian kepegawaian saat pengelolaan data absensi pegawai Politeknik Negeri Ujung Pandang.

b. Interview. Melakukan Interview kepada pegawai yang bertanggung jawab mengelola data absensi pegawai Politeknik Negeri Ujung Pandang sehingga timbul Tanya jawab yang dapat menimbulkan solusi atau apa yang diharapkan.

2) Analisis Kebutuhan

Pada Tahap Analisis Kebutuhan ini dilakukan agar tahap perancangan sistem dapat dibangun sesuai dengan tahapan pengumpulan data yang sebelumnya telah dilakukan. Melalui tahapan itu diketahui bahwa kebutuhan untuk membangun sistem ini terdapat 11 modul yaitu modul login, modul home, modul user, modul aturan 
sanksi, modul aturan waktu terlambat, modul aturan waktu cepat pulang, modul aturan jenis ketidakhadiran, modul aturan jadwal kerja, modul aturan jadwal libur, modul laporan, dan modul pegawai.

\section{3) Perancangan}

Tahap perancangan menentukan proses yang terjadi pada sistem informasi absensi pegawai.

a. Diagram Sistem

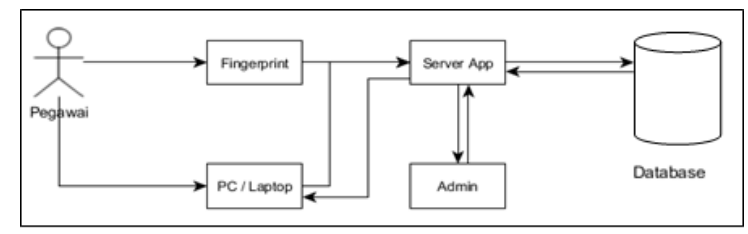

Gambar 3.2 Gambaran Umum Perancangan Sistem

b. Data Flow Diagram

Data flow diagramadalah salah satu diagram yang menyajikan informasi tentang aliran data pada sistem. Adapun aliran data sistem dapat dilihat sebagai berikut.

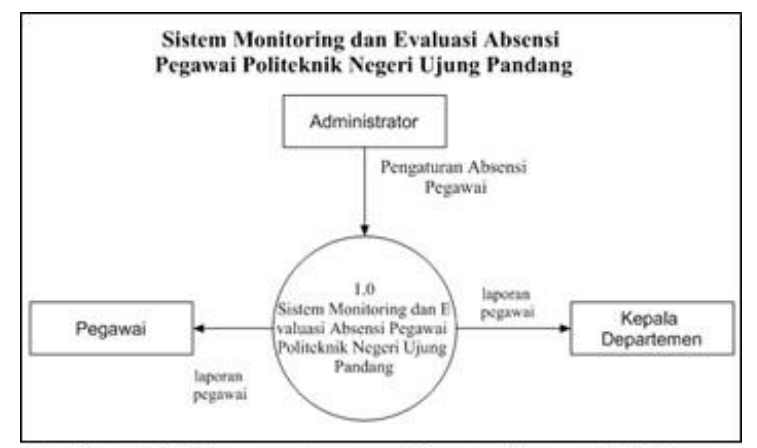

Gambar 3.3 Diagram Context Sistem Absensi PNUP

\section{c. Use Case Diagram}

Use Case Diagram merupakan diagram yang digunakan untuk menggambarkan fungsional yang diharapkan dari sebuah sistem. Use Case Diagram menekankan pada "siapa" melakukan "apa" dalam lingkungan sistem yang akan dibangun. Diagram ini menunjukkan fungsionalitas suatu sistem dan bagaimana sistem tersebut berinteraksi dengan dunia luar.

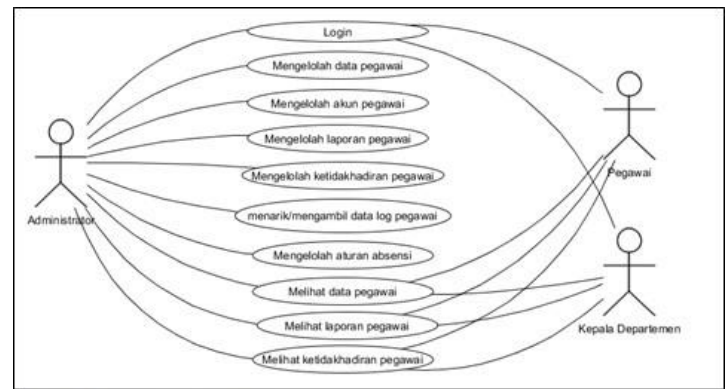

Gambar 3.4 Use Case Diagram

\section{d. Activity Diagram}

Pada activity diagram ini menggambarkan aktivitas admin, pegawai, kepala departemen, dan sistem.

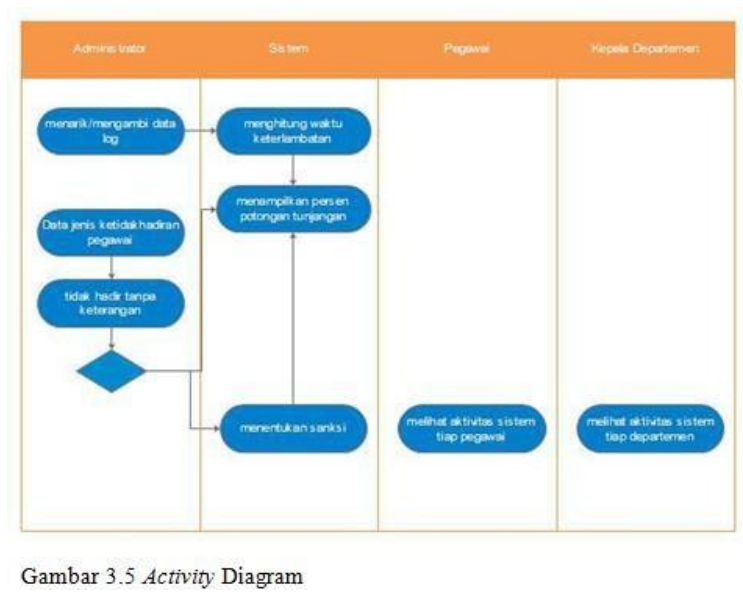

e. Entity Relationship Diagram (ERD)

Entity Relationship Diagram menggambarkan hubungan antara satu entitas dengan entitas lainnya.

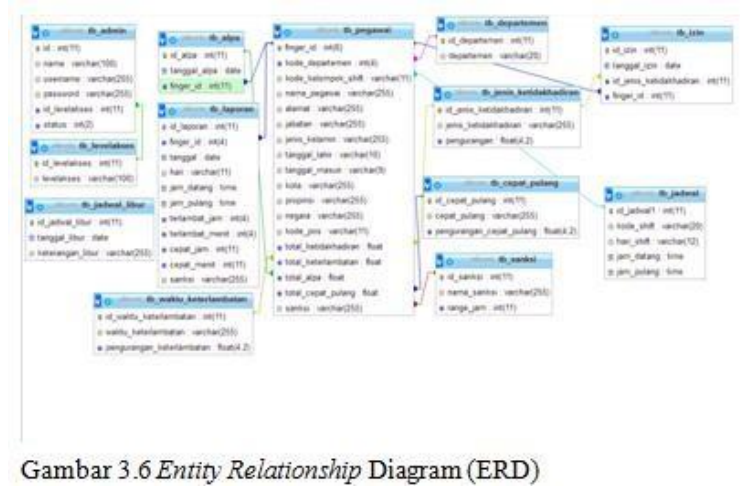

\section{HASIL DAN PEMBAHASAN}

Hasil dari penelitian ini adalah Sistem Monitoring dan Evaluasi Absensi Pegawai Politeknik Negeri Ujung Pandang berbasis WebApp dengan menggunakan framework 
codeigniter. Berdasarkan hasil penelitian ini, maka dilakukan pengujian fungsionalitas sistem yang bertujuan mengetahui tingkat keberhasilan sistem.

1) Pengujian Login Administrator dan Pegawai

Tabel 4.1 Pengujian Login Administrator dan User

\begin{tabular}{|c|c|c|c|c|}
\hline No & Data Masukan & Yang Diharapkan & Pengamatan & Kesimpulan \\
\hline 1. & $\begin{array}{l}\text { Useri: Admin } \\
\text { dan pegawai. } \\
\text { Username dan } \\
\text { Password : } \\
\text { benar }\end{array}$ & $\begin{array}{l}\text { Masuk ke halaman } \\
\text { utama (dashboard) } \\
\text { sesuai hak akses } \\
\text { yang diberikan }\end{array}$ & $\begin{array}{l}\text { Admin dapat } \\
\text { mengelolah data } \\
\text { absensi pegawai } \\
\text { seperti menambah, } \\
\text { mengedit, dan } \\
\text { menghapus data. } \\
\text { - pegawai: hanya } \\
\text { dapat melihat data }\end{array}$ & BERHASIL \\
\hline 2. & $\begin{array}{l}\text { Usermi Admin } \\
\text { dan pegawai. } \\
\text { Username dan } \\
\text { Password : } \\
\text { salah }\end{array}$ & $\begin{array}{l}\text { Tidak dapat masuk } \\
\text { ke halaman utama } \\
\text { (dashboard) dan } \\
\text { muncul keterangan } \\
\text { 'username atau } \\
\text { password salah' }\end{array}$ & $\begin{array}{l}\text { Tidak dapat masuk } \\
\text { ke halaman utama } \\
\text { (dashboard) dan } \\
\text { munculketerangan } \\
\text { 'username atau } \\
\text { password salah' }\end{array}$ & BERHASIL \\
\hline 3. & $\begin{array}{l}\text { Akun pegawai } \\
\text { belum } \\
\text { diaktifkan }\end{array}$ & $\begin{array}{l}\text { Tidak dapat masuk } \\
\text { ke halaman utama } \\
\text { (dashboard) dan } \\
\text { muncul keterangan } \\
\text { "Anda belum } \\
\text { mendapatkan } \\
\text { permission'. }\end{array}$ & $\begin{array}{l}\text { Tidak dapat masuk } \\
\text { ke halaman utama } \\
\text { (dashboard) dan } \\
\text { munculketerangan } \\
\text { 'Anda belum } \\
\text { mendapatkan } \\
\text { permission'. }\end{array}$ & BERHASIL \\
\hline
\end{tabular}

2) Pengujian Data User

Tabel 4.2 Pengujian Data User

\begin{tabular}{|c|l|l|l|l}
\hline No & Data Masukan & Yang Diharapkan & Pengamatan & Kesimpulan \\
\hline 1. & Data user on & $\begin{array}{l}\text { Akun User dapat } \\
\text { masuk kedalam } \\
\text { sistem sesuai } \\
\text { dengan hak akses } \\
\text { masing-masing } \\
\text { akun. }\end{array}$ & $\begin{array}{l}\text { User dapat masuk } \\
\text { kedalamsistem }\end{array}$ & BERHASIL \\
\hline 2. & Data user off & $\begin{array}{l}\text { Akun Usertidak } \\
\text { dapat masuk } \\
\text { kedalamsistem dan } \\
\text { akanada } \\
\text { pemberitahuan }\end{array}$ & $\begin{array}{l}\text { User tidak dapat } \\
\text { masuk kedalam } \\
\text { sistem }\end{array}$ & BERHASIL \\
"Anda Belum \\
$\begin{array}{l}\text { Mendapatkan } \\
\text { Pemission". }\end{array}$ & & \\
\hline
\end{tabular}

3) Pengujian Modul Jadwal Libur

Tabel 4.3 Pengujian Modul Jadwal Libur

\begin{tabular}{|c|c|c|c|c|}
\hline No & Data Masukan & Yang Diharapkan & Pengamatan & Kesimpula1 \\
\hline 1. & $\begin{array}{l}\text { Data jadwal } \\
\text { libur ada }\end{array}$ & $\begin{array}{l}\text { Tanggal pada } \\
\text { laporan pegawai } \\
\text { yangterdapat pada } \\
\text { jadwal liburtidak } \\
\text { akandihitung } \\
\text { sebagaitidak hadir } \\
\text { tanpaketerangan }\end{array}$ & $\begin{array}{l}\text { Tanggal pada } \\
\text { laporan pegawai } \\
\text { yangterapatpada } \\
\text { jadwallibur tidak } \\
\text { akandihitung } \\
\text { sebagaitidak hadir } \\
\text { tanpaketerangan }\end{array}$ & BERHASII \\
\hline
\end{tabular}

4) Pengujian Data Laporan
Tabel 4.4 Pengujian Laporan

\begin{tabular}{|c|c|c|c|c|}
\hline No & Data Masukan & Yang Diharapkan & Pengamatan & Kesimpulan \\
\hline 1. & $\begin{array}{l}\text { Dua data log } \\
\text { yang berisi } \\
\text { finger_id dan } \\
\text { tanggal_log } \\
\text { yangs sama serta } \\
\text { waktu_logpagi } \\
\text { dan sore. } \\
\text { Seperti Gambar } \\
4.38\end{array}$ & $\begin{array}{l}\text { Men ghasilkan satu } \\
\text { data laporan yang } \\
\text { terisi sesuai dengan } \\
\text { kolom yang ada. }\end{array}$ & $\begin{array}{l}\text { Tampil data finger, } \\
\text { tanggal, hari, jam } \\
\text { datang, jam pulang, } \\
\text { waktu terlambat, } \\
\text { dan waktu cepat } \\
\text { pulang. Seperti } \\
\text { gambarr } 4.39\end{array}$ & BERHASIL \\
\hline 2. & $\begin{array}{l}\text { Empat data log } \\
\text { yang berisi dua } \\
\text { data log } \\
\text { masing-masing } \\
\text { data finger_id } \\
\text { dan tanggal_log } \\
\text { yang sama serta } \\
\text { waktu_logpagi } \\
\text { dan sore. } \\
\text { Seperti gambar } \\
4.40\end{array}$ & $\begin{array}{l}\text { Menghasillkan dua } \\
\text { data laporan yang } \\
\text { terisi sesuai dengan } \\
\text { kolom yangada. }\end{array}$ & $\begin{array}{l}\text { Tampil data finger, } \\
\text { tanggal, hari, jam } \\
\text { datang, jam pulang, } \\
\text { waktu terlambat, } \\
\text { dan waktu cepat } \\
\text { pulang. Seperti } \\
\text { gambar } 4.41\end{array}$ & BERHASIL \\
\hline 3. & $\begin{array}{l}\text { Tiga data log } \\
\text { yang berisi } \\
\text { finger_id dan } \\
\text { tanggal_log } \\
\text { yang sama serta } \\
\text { dug data } \\
\text { waktu_log pagi } \\
\text { dan satu data } \\
\text { waktu_log sore. } \\
\text { Seperti gambar } \\
4.42\end{array}$ & $\begin{array}{l}\text { Menghasilkan satu } \\
\text { data laporan yang } \\
\text { terisi sesuai dengan } \\
\text { kolom yang ada dan } \\
\text { jam datang terisi } \\
\text { data waktu_logpagi } \\
\text { yang pertama }\end{array}$ & $\begin{array}{l}\text { Tampil data finger, } \\
\text { tanggal, hari, jam } \\
\text { datang, jam pulang, } \\
\text { waktu terlambat, } \\
\text { dan waktu cepst } \\
\text { pulang. Seperti } \\
\text { gambar } 4.43\end{array}$ & BERHASIL \\
\hline 4. & $\begin{array}{l}\text { Tiga data log } \\
\text { yang berisi } \\
\text { finger_id dan } \\
\text { tanggal_log } \\
\text { yang sama serta, } \\
\text { satud data } \\
\text { waktu_logpagi } \\
\text { dan dua data } \\
\text { waktu_log sore. } \\
\text { Seperti gambar } \\
4.44\end{array}$ & $\begin{array}{l}\text { Menghasilkan satu } \\
\text { data laporan yang } \\
\text { terisi sesuai dengan } \\
\text { kolom yang ada dan } \\
\text { jam pulang terisi } \\
\text { data waktu_log sore } \\
\text { yang pertama }\end{array}$ & $\begin{array}{l}\text { Tampil data finger, } \\
\text { tanggal, hari, jam } \\
\text { datang, jam pulang, } \\
\text { waktu terlambat, } \\
\text { dan waktu cepat } \\
\text { pulang. Seperti } \\
\text { gambar } 4.45\end{array}$ & BERHASIL \\
\hline
\end{tabular}

5) Pengujian Perhitungan Pengurangan Tunjangan Kinerja (Keterlambatan)

Tabel 4.5 Pengujian Perhitungan Pengurangan Tunjangan Kinerja (Keterlambatan)

\begin{tabular}{|c|l|l|l|l|}
\hline No & Data Masukan & Yang Diharapkan & Pengamatan & Kesimpulan \\
\hline 1. & $\begin{array}{l}\text { Terdapat data } \\
\text { terlambat pada } \\
\text { data laporan }\end{array}$ & $\begin{array}{l}\text { Tertera angka } \\
\text { persen pemotongan } \\
\text { pada halaman } \\
\text { pegawai }\end{array}$ & $\begin{array}{l}\text { Jumlah persen } \\
\text { pengurangan } \\
\text { tunjangan sama } \\
\text { dengan jumlah } \\
\text { keterlambatan yang } \\
\text { telah di ubah } \\
\text { menjadi persen } \\
\text { pengurangan sesuai } \\
\text { dengan aturan } \\
\text { keterlambatan }\end{array}$ & BERHASIL \\
\hline 2. & $\begin{array}{l}\text { Tidak terdapat } \\
\text { data terlambat } \\
\text { pada data } \\
\text { laporan }\end{array}$ & $\begin{array}{l}\text { Terdapat 0\% } \\
\text { pemotongan pada } \\
\text { halaman pegawai }\end{array}$ & $\begin{array}{l}\text { Terdapat 0\% } \\
\text { pemotongan pada } \\
\text { halaman pegawai }\end{array}$ & BERHASIL \\
\hline
\end{tabular}

6) Pengujian Perhitungan Pengurangan Tunjangan Kinerja (Cepat Pulang)

Tabel 4.6 Pengujian Perhitungan Pengurangan Tunjangan Kinerja (Cepat Pulang)

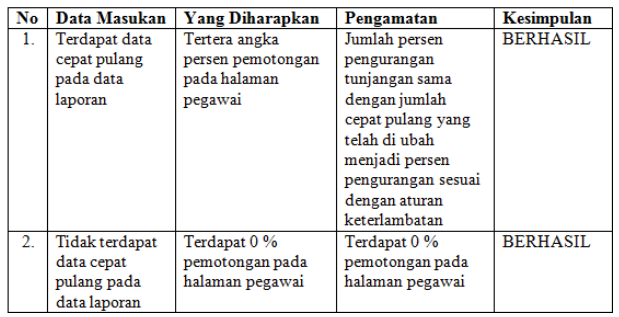

7) Pengujian Perhitungan Pengurangan Tunjangan Kinerja (Absen) 


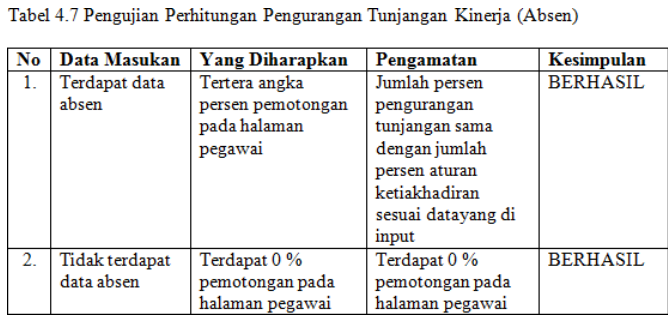

8) Pengujian Perhitungan Pengurangan Tunjangan Kinerja (Izin / Sakit)

Tabel 4.8 Pengujian Perhitungan Pengurangan Tunjangan Kinerja (Izin / Sakit)

\begin{tabular}{|c|l|l|l|l|}
\hline No & Data Masukan & Yang Diharapkan & Pengamatan & Kesimpulan \\
\hline 1. & $\begin{array}{l}\text { Terdapat data } \\
\text { Izin/ Sakit }\end{array}$ & $\begin{array}{l}\text { Tertera angka } \\
\text { persen pemotongan } \\
\text { pada halaman } \\
\text { pegawai }\end{array}$ & $\begin{array}{l}\text { Jumlah persen } \\
\text { pengurangan } \\
\text { tunjangan sama } \\
\text { dengan jumlah } \\
\text { persen aturan } \\
\text { ketiakhadiran } \\
\text { sesuai datayang di } \\
\text { input }\end{array}$ & BERHASIL \\
\hline 2. & $\begin{array}{l}\text { Tidak terdapat } \\
\text { data Izin / Sakit }\end{array}$ & $\begin{array}{l}\text { Terdapat 0 \% } \\
\text { pemotongan pada } \\
\text { halaman pegawai }\end{array}$ & $\begin{array}{l}\text { Terdapat 0 \% } \\
\text { pemotongan pada } \\
\text { halaman pegawai }\end{array}$ & BERHASIL \\
\hline
\end{tabular}

9) Pengujian Data Sanksi

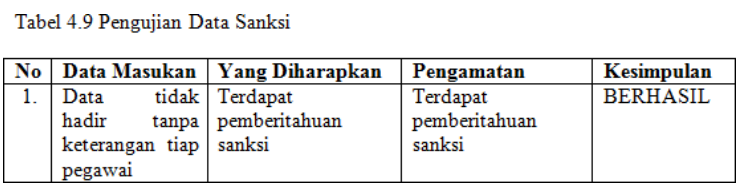

10) Hasil Data Laporan
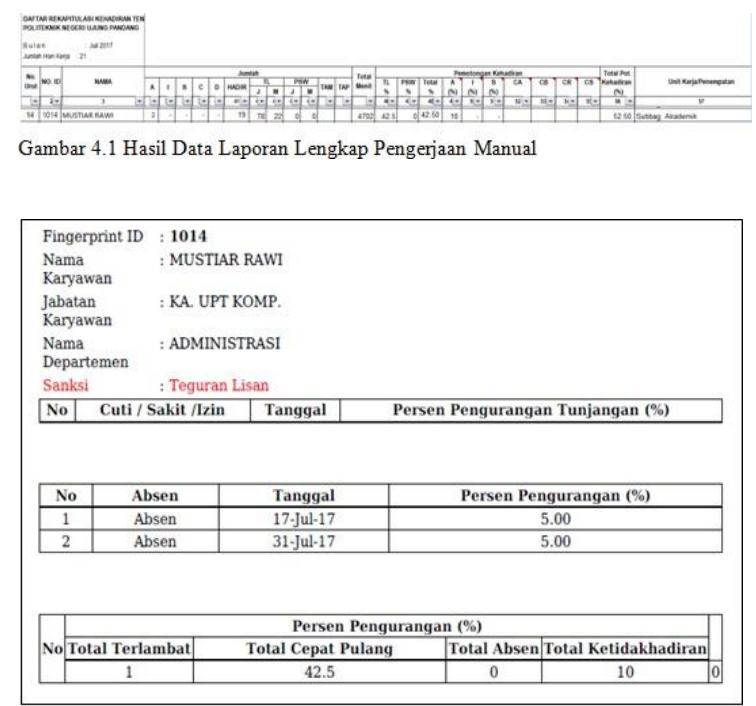

Gambar 4.2 Hasil Data Laporan Lengkap Pengerjaan Sistem

\section{KESIMPULAN}

Kesimpulan yang dapat diperoleh dari perancangan hingga pengujian sistem dapat dilihat sebagai berikut.
1) Sistem monitoring dan evaluasi absensi kepegawaian yang telah dibangun telah diintegrasikan dengan database, sehingga pengolahan data yang terjadi didalam sistem dapat tersimpan dengan baik.

2) Sistem monitoring dan evaluasi absensi kepegawaian yang telah dibangun dapat menentukan waktu keterlambatan dan cepat pulang setiap pegawai menggunakan data log pegawai. Selain itu sistem ini juga dapatmenentukan persen potongan tunjangan kinerja dan menentukan sanksi pegawai.

3) Melalui sistem monitoring dan evaluasi absensi kepegawaain ini setiap pegawai Politeknik Negeri Ujung Pandang dapat melihat aktifitas absensi pegawai tiap bulannya.

4) Dengan adanya sistem monitoring dan evaluasi absensi pegawai ini pengolahan data absensi lebih cepat dan lebih akurat.

Dalam perancangan sistem ini masih terdapat kekurangan sehingga kedepannya dapat dilakukan perbaikan atau pengembangan untuk mendapatkan hasil yang maksimal.

\section{REFERENSI}

[1] Andika, Radenal.2011.Penerapan CI (Codeigniter) dalam Pengembangan Sistem Informasi Manajemen Surart dan Pengarsipan.Jakarta.

[2] Basuki, Awan P. 2010. Membanguan Web Berbasis PHP dengan Framework CodeIgniter. Dalam Skripsi Penerapan CI (Codeigniter) dalam Pengembangan Sistem Informasi Manajemen Surart dan Pengarsipan. (Andika, Radenal). 2011. Jakarta.

[3] Bellina, Mira. 2009. Sistem Informasi Absensi Pegawai Pada CV.FLASHINDOMEDIA Medan 
Berbasis Web. Universitas Sumatera Utara.

[4] Blanco, Jose A. and Upton, David. 2009. CodeIgniter 1.7 dalam Pengembangan Sistem Informasi Manajemen Surart dan Pengarsipan. (Andika, Radenal). 2011. Jakarta.

[5] Dahria, Muhammad. 2011. Metode Akses Data ODBC dan OLE DB. STMIK Triguna Dharma.

[6] Griffiths, Adam. 2010. CodeIgniter 1.7 Professional Development dalam Pengembangan Sistem Informasi Manajemen Surart dan Pengarsipan. (Andika, Radenal). 2011. Jakarta.

[7] Hewitt, Eleanor \& Michael Bamberger. 1986. Monitoring and Evaluating Urban Development Programs. Dalam Jurnal Penyusunan Instrumen Monitoring dan Evaluasi Manfaat Program Pembangunan Di Kota Semarang. (Mohammad Muktiali).2009. Semarang.

[8] Menteri RI. 2016. Peraturan Menteri Riset, Teknologi, dan Pendidikan Tinggi Reublik Indonesia Nomor 31 Tahun 2016 Tentang Pemberian Tunjangan Kinerja Pegawai di Lingkungan Kementrian Riset, Teknologi, dan Pendidikan Tinggi.

[9] Muktiali, Mohammad. 2009. Penyusunan Instrumen Monitoring dan Evaluasi Manfaat Program Pembangunan Di Kota Semarang. Semarang.

[10] Ojha, Durga. 1998. Impact Monitoring Approaches and Indicators.Dalam Jurnal Penyusunan Instrumen Monitoring dan Evaluasi Manfaat Program Pembangunan Di Kota Semarang. (Mohammad Muktiali).2009. Semarang.
[11] Prasetyo, Budi dkk. 2015. Perancangan dan Pembuatan Sistem Informasi Gudang (Studi Kasus : PT. PLN (Persero) Area Surabaya Barat. Surabaya.

[12] Presiden RI. 2010. Peraturan Pemerintah Republik Indonesia Nomor 53 Tahun 2010 Tentang Disiplin Pegawai Negeri Sipil.

[13] Ratna, Adis Lena Kusuma. 2014. Pengertian PHP dan MySQL. Tanggerang.

[14] Setiawan, Eko Budi.2015.Perancangan Sistem Absensi Kehadiran Perkuliahan dengan Menggunakan Radio Frequency Identification (RFId).Bandung

[15] Utomo, Sigit Prasetyo Karisma.2014.Pembuatan Sistem Informasi Berbasis Website pada SD Masjid Syuhada Yogyakarta Menggunakan Framework Codeigniter dan Bootstrap.Yogyakarta

[16] Widhyarini.2010.Analisis dan Perancangan Sistem Presensi Karawan Menggunakan Sidik Jari di Aba Yipk Yogyakarta. Yogyakarta

[17] Winarti, Dwi. Tanpa Tahun.Pengembangan Aplikasi Absensi Pegawai Berbasis Web dan Absensi Siswa Berbasis Sms Sma Negeri 1 Imogiri. Yogyakarta

[18] Yogiyanto, H. M. 2005. Analisis dan Desain Sistem Informasi: Pendekatan Terstruktur Teori dan Praktik Aplikasi Bisnis. Dalam Artikel Pengembangan Aplikasi Absensi Pegawai Berbasis Web dan Absensi Siswa Berbasis Sms Sma Negeri 1 Imogiri. (Dwi Winarti). Tanpa Tahun. Yogyakarta 